\title{
Department of Energy Plan for Recovery and Utilization of Nuclear Byproducts from Defense Wastes -
}

\section{Executive Summary}

August 1983
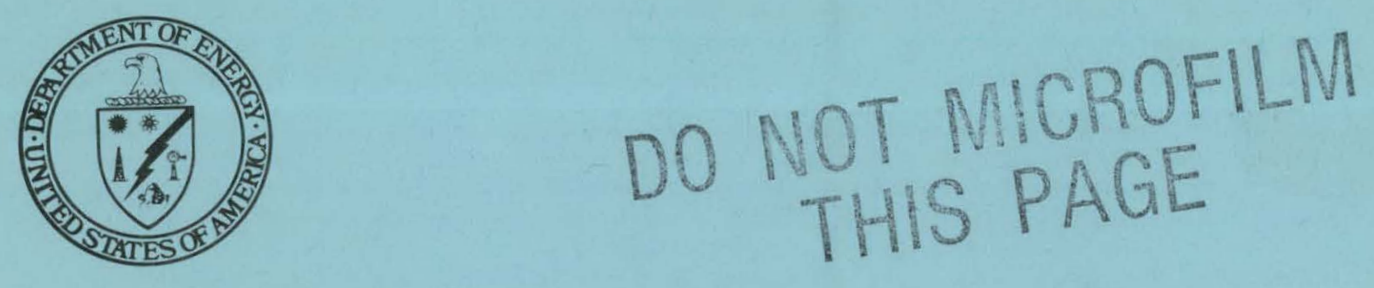

U.S. Department of Energy Assistant Secretary for Defense Programs Office of Defense Waste and Byproducts Managenient 


\section{DISCLAIMER}

This report was prepared as an account of work sponsored by an agency of the United States Government. Neither the United States Government nor any agency Thereof, nor any of their employees, makes any warranty, express or implied, or assumes any legal liability or responsibility for the accuracy, completeness, or usefulness of any information, apparatus, product, or process disclosed, or represents that its use would not infringe privately owned rights. Reference herein to any specific commercial product, process, or service by trade name, trademark, manufacturer, or otherwise does not necessarily constitute or imply its endorsement, recommendation, or favoring by the United States Government or any agency thereof. The views and opinions of authors expressed herein do not necessarily state or reflect those of the United States Government or any agency thereof. 


\section{DISCLAIMER}

Portions of this document may be illegible in electronic image products. Images are produced from the best available original document. 


\section{DO NOT MICROFILM THIS PAGE}

Printed in the United States of America Available from

National Technical Information Service United States Department of Commerce 5285 Port Royal Road Springfield, Virginia 22151

\section{Price: Printed Copy $\quad$ A02} Microfiche A01

Codes are used for pricing all publications. The code is determined by the number of pages in the publication. Information pertaining to the pricing codes can be found in the current issues of the following publications, which are generally available in most libraries: Energy Research Abstracts, (ERA); Government Reports Announcements and Index (GRA and I); Scientific and Technical Abstract Reports (STAR); and publication, NTIS-PR-360 available from (NTIS) at the above address. 
DOE/DP-0013

Vol. 1 of 2

Dist. Category UC-70

\section{Department of Energy Plan for Recovery and Utilization of Nuclear Byproducts from Defense Wastes}

\section{Executive Summary}

DOE/DP--0013-Vol.1

DE83 017049

August 1983

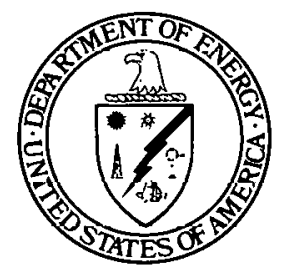

\section{DISCLAIMER}

This report was prepared as an account of work sponsored by an agency of the United States Government. Neither the United States Government nor any agency thereof, nor any of their employees, makes any warranty, express or implied, or assumes any legal liability or responsibility for the accuracy, completeness, or usefulness of any information, apparatus, product, or process disclosed, or represents that its use would not infringe privately owned rights. Reference herein to any specific commercial product, process, or service by trade name, trademark, manufacturer, or otherwise does not necessarily constitute or imply its endorsement, recommeñdation, or favoring by the United States Government or any agency thereof. The views and opinions of authors expressed herein do not necessarily state or reflect those of the United States Government or any agency thereof.

\section{NOTHCE}

PORTIORS OF THIS REPORT ARE ILLEGIBLE.

It has been reproduced from ine best available copy to permit the broadest. possible availability.

\section{U.S. Department of Energy Assistant Secretary for Defense Programs Office of Defense Waste and Byproducts Management Washington, D.C. 20545}




\section{THIS PAGE}

\section{WAS INTENTIONALLY \\ LEFT BLANK}




\section{Contents}

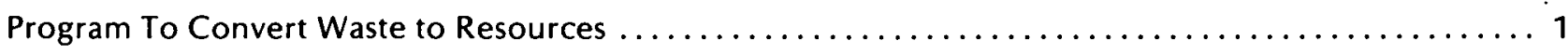

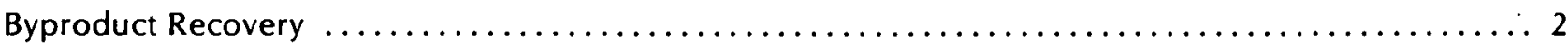

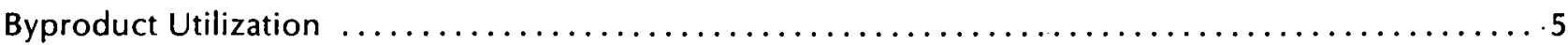

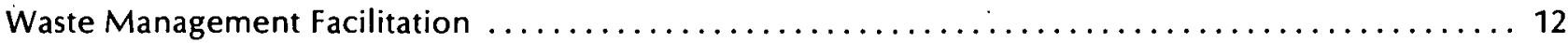

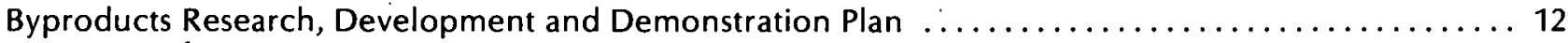

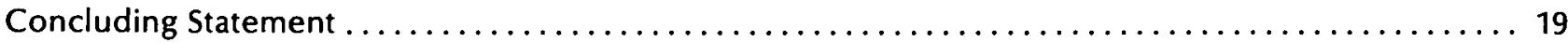

\section{Illustrations}

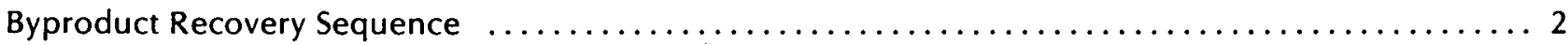

Cumulative Inventory of Heat-Source Grade Strontium-90 Available

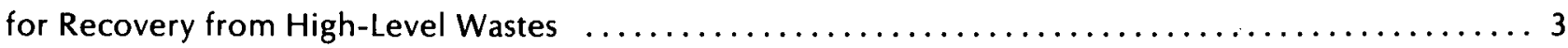

Cumulative Inventory of Cesium-137 Available from High-Level Wastes

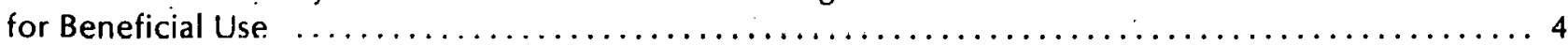

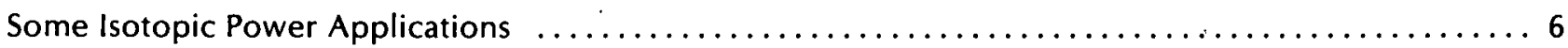

Cesium-137 Pilot-Plant Irradiator at Sandia National Laboratories $\ldots \ldots \ldots \ldots \ldots \ldots \ldots \ldots \ldots \ldots \ldots 8$

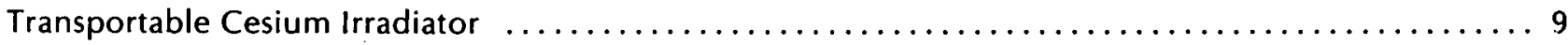

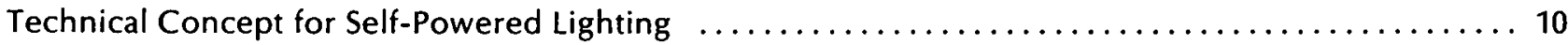

Remote Runway Lighting Using Self-Powered Radioluminescent Lights $\ldots \ldots \ldots \ldots \ldots \ldots \ldots \ldots$

Three of Several Configurations of Self-Powered Lights Being Developed

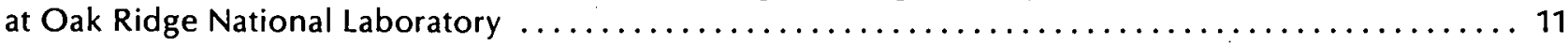

Cooperative Support of Low-Dose Cesium-137 Food Irradiation Program $\ldots \ldots \ldots \ldots \ldots \ldots \ldots \ldots$

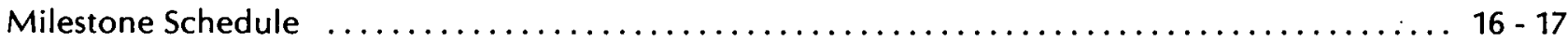

\section{Tables}

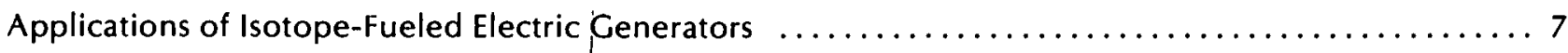

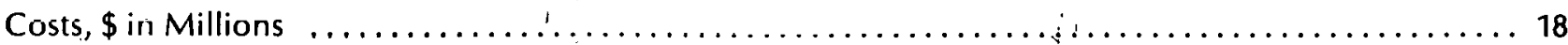




\section{Department of Energy Plan for Recovery and Utilization of Nuclear Byproducts from Defense Wastes - Executive Summary}

\section{Program To Convert Waste to Resources}

Nuclear wastes from the defense production cycle contain many uniquely useful, intrinsically valuable, and strategically important materials. These materials have a wide range of known and potential applications in food technology, agriculture, energy, public health, medicine, industrial technology, and national security. Furthermore, their removal from the nuclear waste stream has the potential to facilitate waste management and yield economic, safety, and environmental advantages in the management and disposal of the residual. nuclear wastes that have no redemptive value.

A program plan has been prepared which details the planned research, development, and demonstration (RD\&D) to stimulate the effective use of these valuable byproducts. This plan should be recognized as an initial effort which will be updated annually to reflect refinements and revisions made as the program matures. This summary of a more comprehensive document, DOE/DP-0013, Vol. 2, August 1983, that gives details of the program plan, provides the general conclusions and major direction of the Department of Energy's (DOE) plan.

Because of the potential value of byproduct recovery and use, as well as the desire to convert a perceived national liability into a national resource, it is the policy of DOE's Defense Programs to encourage widespread use of byproducts in meeting unique national needs and in solving major national and societal problems. To implement this policy, goals have been set for an integrated research, development, and demonstration program with byproducts from defense and other nuclear activities as appropriate.

The three primary program elements are byproduct recovery, byproduct application, and the impact of these activities on nuclear waste management. The program elements will be implemented in a safe, environmentally acceptable, cost-effective manner. The research, development, and demonstration of byproduct applications will be a cooperative, resource-sharing activity among DOE Defense Programs and known and potential users in the Federal, State, and private sectors as well as foreign states and international agencies. The feasibility, safety, and environmental attributes of each application will be demonstrated prior to commercialization or routine operations. The DOE program will be designed to stimulate use of byproducts by industry through rapid transfer of technology.

DOE is committed to aid in the supply of useful byproducts, to assist in the demonstration of meaningful applications, and to perform RD\&D in areas of high technology and economic risk. Each element of the program and each application is characterized by a clearly defined state of development which provides for the orderly termination of DOE involvement. The extent to which DOE participates in the development will be a function of the present state of the technology, status of institutional issues, and the maturity of national policy.

The goal of this program plan is to define a national DOE program to meet the following objectives in the three program elements.

\section{Byproduct Recovery}

- Assess the feasibility and economics of recovering various materials.

- Assess the compatibility of byproduct recovery processes with production and waste management processes.

- Recover, recycle, and conserve national resources and strategic materials.

- Provide a current inventory of byproducts, scrap materials, and other potential resources in the defense production complex and in the civilian fuel cycle.

\section{Byproduct Utilization}

- Identify applications and assess the technical and economic viability of byproduct applications.

- Perform systems analyses to ensure that the cost/ benefit of byproduct use compares favorably with alternative solutions.

- Identify unique military needs related to byproduct utilization and support the Department of Defense in product development.

- Determine byproduct quality criteria and user requirements that will facilitate recovery, utilization, and final disposal. 
- Deploy demonstration systems jointly with users and transfer byproduct technology to users expeditiously.

- Ensure that each application incorporates due consideration of environmental, safety, and health factors.

\section{Waste Management Facilitation}

- Identify mechanisms where byproduct extraction can improve waste management and disposal operations and facilities.

- Determine the economic impact of byproduct recovery on waste management operations from reactor discharge to disposal of all wastes and end-of-life disposal of byproducts.

- Seek compatibility of byproduct recovery and waste management processes.

The byproducts program will require a variety of interfaces with other government and private agencies, including regulatory agencies, users and international organizations. Such interfaces will be established as needed, recognizing that early iden- tification and closure will enhance the program's management and progress.

The following sections of this summary describe some of the demonstrated and potential applications of nuclear byproducts, the inventory of byproducts for such application, and the influence that byproduct removal will have on waste management. Finally, the major goals of the program plan will be cited, with estimates of the required costs and schedules to achieve these goals.

\section{Byproduct Recovery}

Over 500 isotopes are produced in nuclear reactors by fission and irradiation processes. The quantity and potential for useful applications of these isotopes vary over a wide range, and only a relarlvely small number can be collsidered fur application in the near term. Several of these isotopes have been recovered and used for beneficial application, and techniques can be developed for recovery of others as conditions warrant. A generalized scheme for recovery of some of the major byproducts is shown.

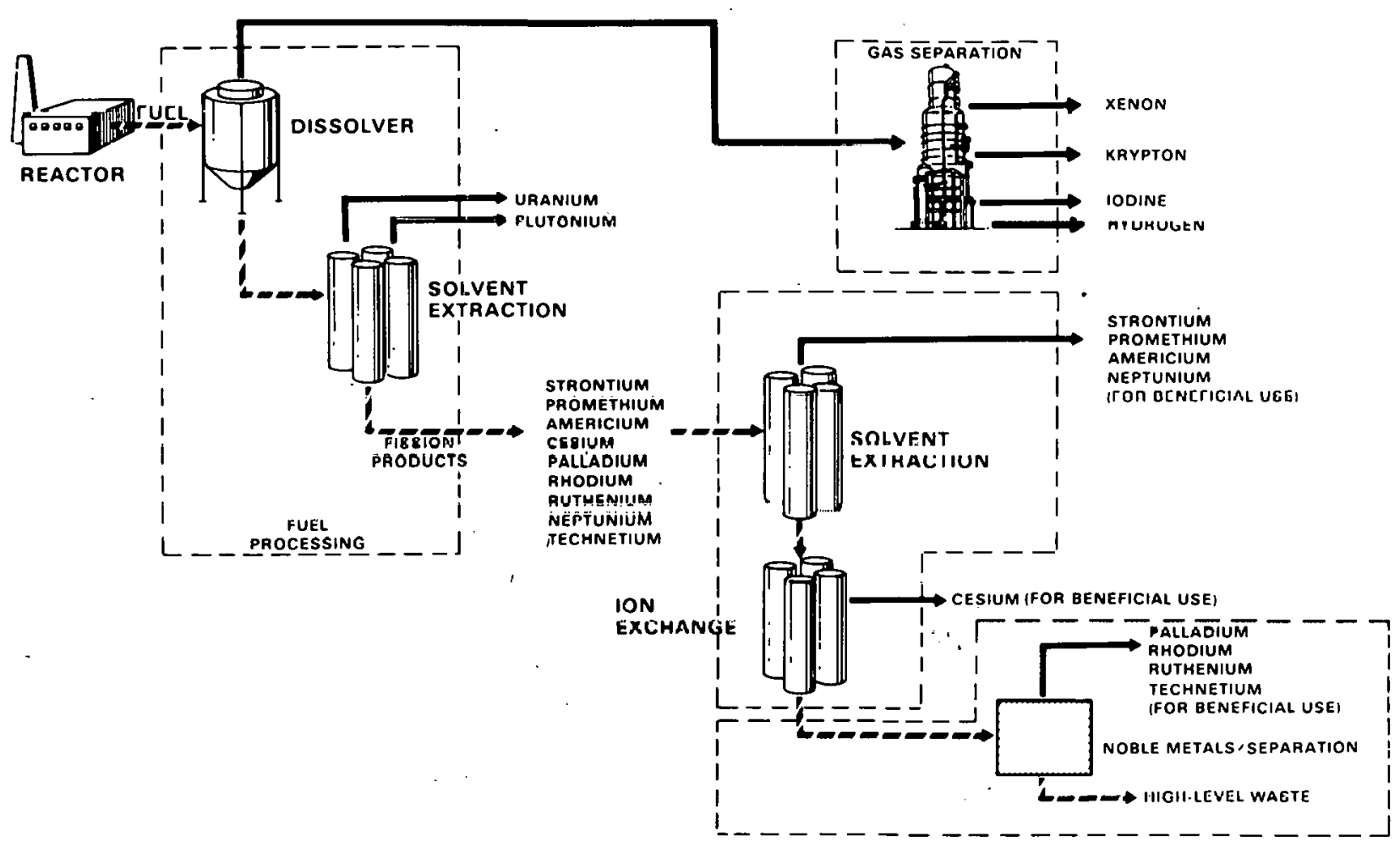

Byproduct Recovery Sequence 


\section{Nuclear Byproduct Inventories and Availability}

The nuclear byproducts treated in this section include strontium, çesium, krypton, tritium, xenon, palladium, rhodium, ruthenium, technetium, promethium, neptunium, americium and curium. These materials are potentially available from currently stored waste and future processing at Hanford, at the Savannah River Plant (SRP), and at the Idaho Chemical Processing Plant (ICPP), and from future processing of commercial spent fuel. In addition, technetium is recovered during uranium isotope enrichment, and americium recovered during reprocessing of previously purified plutonium.

Commercial spent fuels represent a major source of byproducts if processing of commercial fuels is restarted. The current inventory of commercial spent fuel, through 1981 , is about 8000 metric tons of initial heavy metal (MTIHM).

Although a byproduct may be potentially recoverable from a given source, it does not necessarily follow that recovery is either technically or economically feasible. At present, facilities for recovering, purifying and packaging of byproducts are limited. Cesium and strontium are recovered and packaged at Hanford. Cesium recovery, but not packaging, is currently being considered at SRP for waste management purposes. Neptunium-237 is recovered at SRP and converted to plutonium238. Krypton and xenon are recovered at ICPP, with some enrichment at Oak Ridge National Laboratory (ORNL).

The following paragraphs summarize the current and potential supply of nuclear byproducts that are projected to receive the highest demand. The energy data presented for the various isotopes are given for the entire decay chain (i.e., power values for strontium-90 in thermal watts are the combined values for the decay of strontium-90 and its yttrium-90 daughter).

\section{Strontium}

The estimated available RTG-grade strontium90 through the year 2000, with applicable assumptions, is shown graphically.

The data show that $80 \mathrm{~kW}_{\mathrm{t}}$ of high-quality strontium- 90 is avallable now at Hanford. The rest of the strontium stored at Hanford and SRP in waste sludge appears to have insufficient heat output for use in RTGs due to the long decay time of strontium-90 or dilution during processing. Assuming an $8 \%$ electrical conversion efficiency for thermo-

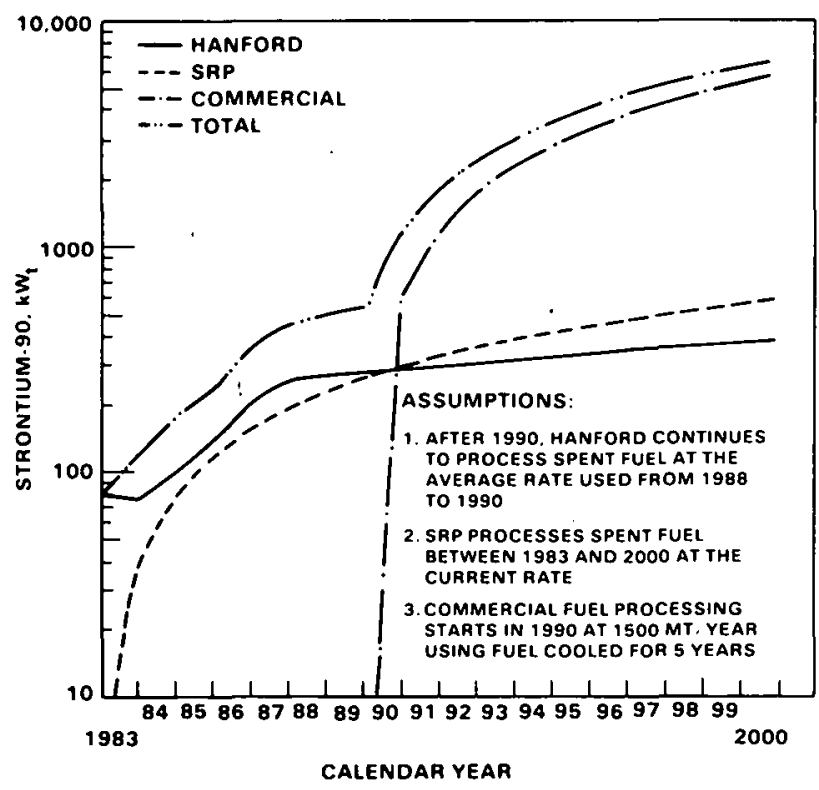

Cumulative Inventory of Heat-Source Grade Strontium-90 ( ${ }^{90} \mathrm{Sr} / \mathrm{Sr} \geqq 40 \%$ ) Available for Recovery from High-Level Wastes

electric generators, the $80 \mathrm{~kW}_{\mathrm{t}}$ translates to 6.4 $\mathrm{kW}_{\mathrm{e}}$, or enough material to power several demonstration units, depending upon their size, between 1983 and 1988. Successful performance of these units should justify construction of the needed facilities at SRP to make significantly more material available. When commercial fuel processing is restarted, the desirability of including strontium recovery facilities should be carefully evaluated. Their inclusion more than doubles the available strontium-90 after 1990.

The projected availability of strontium- 90 suggests that sufficient quantities would be available to fuel up to eighty $100-W_{e}$ RTGs by 1985 from present material and future PUREX operation at Hantord. This, of course, assumes that operation of the strontium separations plant is activated at the time of PUREX restart. Strontium-90 separations at Hanford and at the Savannah River Plant and commercial reprocessing would supply sufficient material for $40 \mathrm{~kW}_{\mathrm{e}}$ for deployment by about 1990.

The technology currently exists to improve the efficiency of power generation to 25 or $30 \%$ using advanced dynamic cycle conversion such as Stirling or gas turbine generators, and the potential exists for efficiencies in excess of $40 \%$. If these systems are developed for use, the potential power achievable with present inventories of high-grade strontium90 is over $25 \mathrm{~kW}$, with the potential of $400 \mathrm{~kW}_{\mathrm{e}}$ by 
1990. Furthermore, lower grade strontium may be economically feasible with these higher efficiency generators, making an additional $100 \mathrm{~kW}$ available by 1985 .

\section{Cesium}

The minimum cesium- 137 content of fissionproduct cesium acceptable for use in irradiators has not been specified. If it is assumed that the cesium-137 remains useful for one half-life following reactor discharge, the minimum useful cesium- $137 /$ cesium ratio would be about $20 \%$. In the absence of any isotopic analyses on the cesium wastes, it was assumed that all recoverable cesium at both Hanford and SRP could be used. Cesium recovery at SRP is planned, but no facilities are currently available tor conversion to the desired form nr pnrapsulation

The estimated cumulative inventory of recoverable cesium- 137 is shown in the graph. These data show that $90 \mathrm{MCi}$ of cesium-137 are currently available at Hanford for irradiator utilization. A "typical" irradiator would use 2 to $10 \mathrm{MCi}$, so the current inventory is sufficient to fuel 20 to 40 "typical" irradiators. As the demand for cesium- 137 increases beyond the supply at Hanford, it will be necessary to construct facilities at SRP for packaging the cesium gamma source, and the cumulative amount of cesium-137 recoverable from Hanford opera-

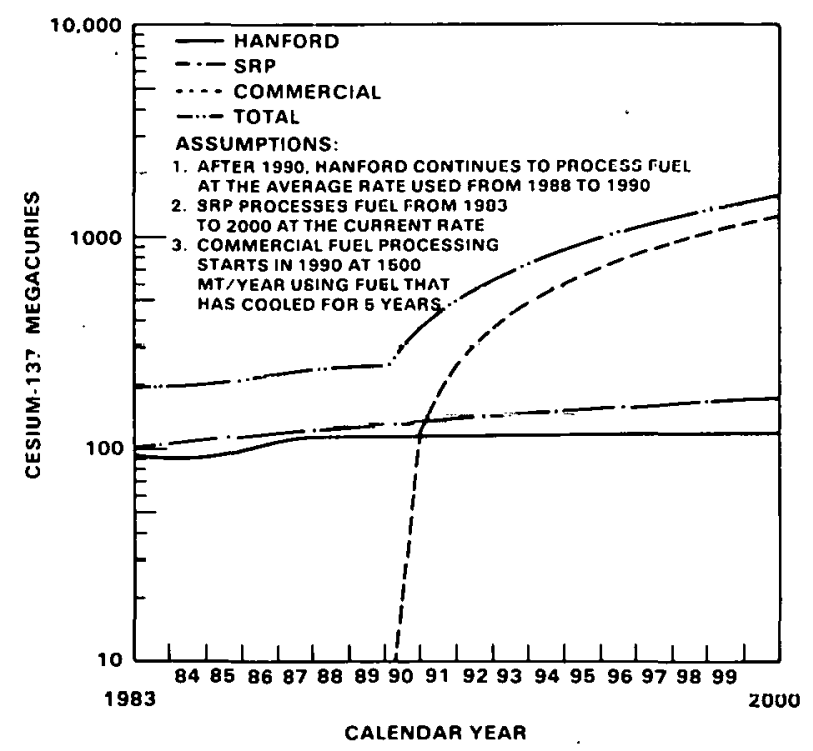

Cumulative Inventory of Cesium-137 Available from High-Level Wastes for Beneficial Use tions and from SRP by 1990 will be about $250 \mathrm{MCi}$. This amount alone will support a substantial irradiation industry. Beyond 1990 the available cesium-137 could be greatly increased by including cesium- 137 recovered from commercial power reactor fuel.

\section{Krypton/Xenon}

At present, krypton and xenon are recovered from processing of aluminum-clad fuel at ICPP. The current shortfall in the supply of krypton-85 is caused by the processing schedule, not by availability. The current estimated annual need for krypton- 85 is $20 \mathrm{kCi}$ to $30 \mathrm{kCi}$, or about $3 \%$ of the annual release of krypton- 85 from defense reprocessing plants. Construction of improved recovery facilitıes at ICPr or of a smäll recovery plant at Hanluid ur SRP shiuuld meet all market needs. Current $L P A$ regulations will require recovery of $85 \%$ of the krypton-85 generated in commercial reactors after January 1, 1983. Enforcement of these regulations should make krypton- 85 and xenon readily available for byproduct application when commercial processing is restarted.

\section{Strategic Platinum Group Metals}

The current defense wastes at Hanford and SRP contain an estimated $1400 \mathrm{~kg}$ of palladium, $2000 \mathrm{~kg}$ of rhodium and $6800 \mathrm{~kg}$ of ruthenium. Continued processing through the year 2020 at currently anticipated schedules will increase these inventories by 40 / to $50 \%$. By far the most significant source of fission-product platinum group metals is spent commercial fuel. By the year 2021 this fuel will contain an estimated $180,000 \mathrm{~kg}$ of palladium, $66,000 \mathrm{~kg}$ of rhodium, and $330,000 \mathrm{~kg}$ of ruthenium.

Thus, fission-products could supply about $10 \%$ of the palladium and $50 \%$ of the rhodium need for the U.S. and several times the projected need for ruthenium. This quantity would appear to meet the strategic necds for palladium, rhodium, and ruthe. nium of the country and perhaps contribute to meeting the needs of platinum, which could be met by these similar metals. Utilization of these materials will require: 1) develupment of proresses and constrürtion of facilitiss that will adequately separate them from the other fission products and 2) proper management of the radioactive palladium, rhodium and ruthenium isotopes.

\section{Neptunium}

Neptunium-237 is currently recovered at SRP and is irradiated for the production of plutonium- 
238. Current needs are met by this source, and recovery of neptunium- 237 is not currently planned when the Hanford PUREX Plant restarts.

\section{Technetium, Promethium and Americium}

Promethium and americium have found limited use in specialized applications in the past and could be used extensively if a variety of potential applications developed. Promethium uses include beta lights, portable X-ray devices, and gun sights. Americium has widespread use in smoke detectors and oil-well logging, and many other applications in instrumentation and analysis have been proposed. Although there are no significant present applications for technetium, it appears to have considerable potential as a catalyst, a corrosion inhibitor, and a coating in marine application to prevent biofouling.

The current requirements for americium-241 are satisfied by recovery from reprocessing of previously purified plutonium. Optimistically projected needs for technetium-99, promethium-147 and americium-241 represent less than $10 \%$ of the amounts of these materials that could be recovered at SRP or Hanford production sites. Some additional processing equipment and facilities would need to be installed to recover these isotopes.

\section{Curium}

Curium-244 may be used in selected applications where the spontaneous fission can be tolerated. There are no significant amounts in defense wastes, but current commercial spent fuel contains $93 \mathrm{~kg}\left(262 \mathrm{~kW}_{\mathrm{t}}\right)$, and by the year 2020 the amount will increase to $1800 \mathrm{~kg}\left(5200 \mathrm{~kW}_{\mathrm{t}}\right)$.

\section{Availability and Cost of Isotopes}

As stated earlier, present defense nuclear fuels processing plants are not designed to recover byproducts except at Hanford, where strontium and cesium have been recovered to facilitate waste management. The current base plan for management of nuclear waste at Hanford includes neutralization of the acidified waste stream followed by separation and temporary tank storage of the precipitated sludge and the supernatant liquid. The supernate may be further treated to remove cesium and the residue immobilized and stored near the surface. In the present plan, the sludge would be treated to remove the strontium-90, and the remaining waste immobilized and placed in a deep geologic repository. Alternative immobilization methods include vitrification in a glass matrix or solidification in a concrete grout.

The plan for waste management at the Savannah River Plant includes removal of the cesium from the supernate, with the sludge being immobilized in glass in the Defense Waste Processing Facility prior to deep geologic storage.

Since both the cesium and strontium will be removed from the waste stream at Hanford for waste management purposes, the cost of these byproducts can be limited to the incremental costs associated with purification and encapsulation specific to the application.

\section{Isotope Separation}

The almost simultaneous advent of the development and demonstration of several processes for separating isotopes (laser isotope separation, plasma separation, and gas centrifuge) has added a new dimension to the concept of extracting and beneficially using byproducts from high-level nuclear waste. Advanced isotope separation techniques offer the first opportunity to decontaminate platinum group metals of their radioactive isotopes rhodium-102, palladium-107, and ruthenium-106, for unlimited use. The separation of other isotopes using these advanced techniques is being actively explored. Among the candidates are strontium-90 for heat and power sources and several isotopes having application in nuclear medicine. Other examples include enrichment of krypton-85 to supply a more concentrated beta source, and removal of residual krypton- 85 from fission-product xenon, leaving the xenon gas free of radioactivity.

\section{Byproduct Utilization}

Byproducts from the nuclear fuel cycle have in the past found a variety of applications, and many possible applications are considered. The following describes the major past and potential applications.

\section{Heat and Power Sources}

One major application of nuclear byproducts is the use of heat-generating isotopes for both heat and power sources. Plutonium-238, obtained from irradiation of the nuclear byproduct neptunium-237, has been used to power low-to-medium power radioisotope thermoelectric generators (RTG) for space, moon landings, and control systems. Plutonium-238 powered RTGs have been used successfully in space since 1961. These power systems have been highly reliable, providing up to 500 watts 
of continuous, stable power to spacecraft used by NASA and DOD missions. Exploratory missions to the planets would have been impossible without such heat and power sources. Both plutonium-238 and promethium- 147 have also been demonstrated as power sources for heart pacemakers and considered for heart pumps and prosthetic devices.

The byproduct of greatest interest for terrestrial power generation is the fission product strontium90 , which, along with its short-lived daughter, yttrium-90, yields 0.93 thermal watts of power $\left(W_{t}\right)$ per gram of the isotope. Furthermore, its recovery has been demonstrated on a production scale at the Hanford Site, where it has been separated and encapsulated to reduce the heat output from the nuclear waste stream to facilitate waste handling. RTG units with over one hundred electrical watts
$\left(\mathrm{W}_{\mathrm{e}}\right)$ of power have been built, and RTGs having capacities of $500 \mathrm{We}_{\mathrm{e}}$ are considered possible.

Failures of the present RTGs are rare, and manufacturers report over $5,000,000$ hours of successful operation. Furthermore, these power devices require no maintenance, are not affected by climatic conditions or electromagnetic shock, and can be designed to resist natural or man-directed destructive forces. Pictured are various terrestrial applications of RTGs, and listed in tabular form are terrestrial and space applications of RTGs.

The availability of this reliable, self-contained, easily hardened, long-lived power source is critical to a wide variety of military and civilian applications. Foremost among these applications are military power sources for command, control, communications, and intelligence $\left(\mathrm{C}^{3} \mathrm{l}\right)$ and low-power

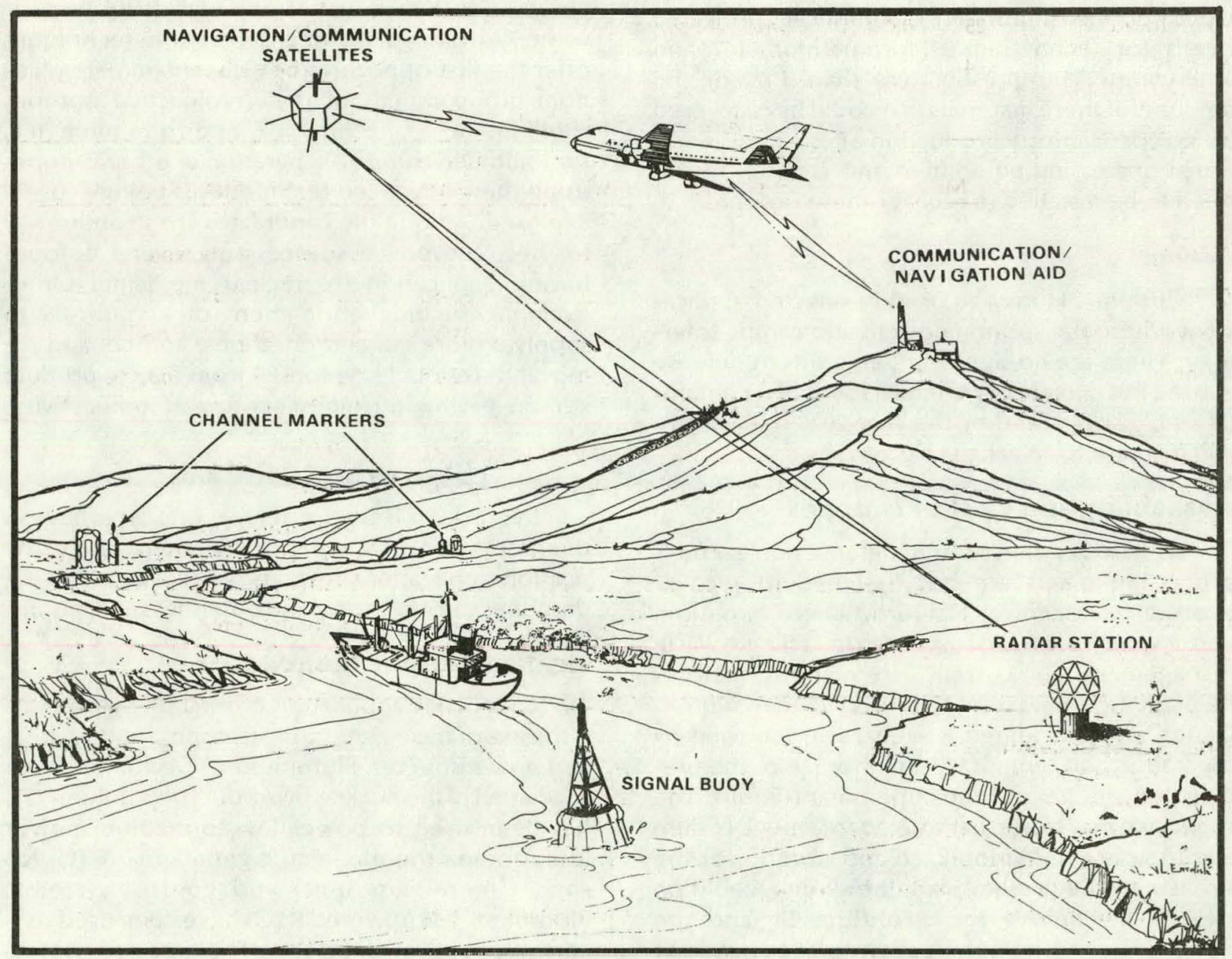

Some Isotopic Power Applications 
Terrestrial

\begin{tabular}{|c|c|c|c|c|c|c|}
\hline $\begin{array}{c}\text { Generator } \\
\text { Model }\end{array}$ & $\begin{array}{l}\text { No. } \\
\text { Mfd. }\end{array}$ & $\begin{array}{l}\text { Power, } \\
\text { watts } \\
\end{array}$ & Year & \multicolumn{2}{|c|}{ Application } & Status \\
\hline${ }^{90} \mathrm{Sr}$-fueled & 1 & 10 & 61 & \multicolumn{2}{|c|}{ Arctic Weather Station } & 2 vears service demo \\
\hline SNAP-7 series & 6 & $10-60$ & $61-65$ & \multicolumn{2}{|l|}{ USCG - USN } & $\begin{array}{l}\text { In storage or defueled; } \\
4 \text { in storage }\end{array}$ \\
\hline Sentinel 25 & 24 & 25 & $66-77$ & \multicolumn{2}{|c|}{$\begin{array}{l}\text { Subsea, communications, } \\
\text { weather }\end{array}$} & $\begin{array}{l}20 \text { operating or being } \\
\text { refurbished }\end{array}$ \\
\hline Sentinel 3 & 3 & 3 & 67 & \multicolumn{2}{|l|}{ Subsea } & In storage \\
\hline Sentinel 8 & 23 & 8 & $68-82$ & \multicolumn{2}{|c|}{ Weather, communications } & Operating \\
\hline Sentinel $100 \mathrm{~F}$ & 1 & 100 & 72 & \multicolumn{2}{|c|}{ Computer power source } & Scheduled USAF, Alaska \\
\hline Sentinel $1 S$ & 4 & 1 & 82 & \multicolumn{2}{|c|}{ Communications relay } & Operating \\
\hline $\begin{array}{l}\text { 238Pu-fueled } \\
\text { High-Performance } \\
\text { Generators }\end{array}$ & 8 & 150 & $76-82$ & \multicolumn{2}{|l|}{ Power } & Operating \\
\hline 75 Milliwatt & 25 & 0.075 & $76-82$ & \multicolumn{2}{|l|}{ Power } & Operating \\
\hline 5 Watt & 4 & 5 & 84 & \multicolumn{2}{|l|}{ Power } & To be delivered \\
\hline \multicolumn{7}{|c|}{ Space, ${ }^{238} \mathrm{Pu}$-fueled } \\
\hline Mission & \multicolumn{2}{|c|}{$\begin{array}{c}\text { No. of } \\
\text { Missions }\end{array}$} & $\begin{array}{c}\text { No. of } \\
\text { Generators }\end{array}$ & $\begin{array}{c}\begin{array}{c}\text { Power, } \\
\text { watts }\end{array} \\
\end{array}$ & $\begin{array}{c}\text { Launch } \\
\text { Dates }\end{array}$ & Status \\
\hline Transit & & 6 & 6 & $2.5-25$ & $61-72$ & 5 in orbit; 1 aborted \\
\hline Nimbus & & 2 & 4 & 30 & $68-69$ & 1 in orbit; 1 aborted \\
\hline Apollo & & 6 & 6 & 70 & $69-72$ & 5 on moon; 1 aborted \\
\hline Pioneer & & 2 & 8 & 40 & $72-73$ & $\begin{array}{l}\text { Successfully operated to } \\
\text { Jupiter and Saturn }\end{array}$ \\
\hline Viking & & 2 & 4 & 40 & 75 & On Mars \\
\hline LES & & 1 & 4 & 150 & 76 & In orbit \\
\hline Voyager & & 2 & 6 & 150 & 77 & $\begin{array}{l}\text { Successfully operated to Jupiter } \\
\text { (79), Saturn (80-81). In transit to } \\
\text { Uranus (86) and Neptune (89). }\end{array}$ \\
\hline Galileo & & 1 & 2 & 285 & 86 & To be delivered \\
\hline Solar Polar & & 1 & 1 & 285 & 86 & To be delivered \\
\hline
\end{tabular}

\section{Proposed Applications}

Remote power sources

Air surveillance

Communication, Command, Control, Intelligence

Animal tracking small battery

Undersea power for oil exploration, navigation, and communications
Civilian

Military

Military

Civilian

Civilian and Military 
radar for defense. It now appears that these applications may require a major fraction of the potential high-grade strontium- 90 available. Its utilization will fulfill a major national need and at the same time remove the major heat-producing isotope from the nuclear waste to facilitate its disposal.

Power generation from radioactive isotopes currently appears to require heat sources with a power density approaching $1 \mathrm{watt} / \mathrm{cm}^{3}$. It is anticipated that strontium obtained from future nuclear fuel reprocessing will have a strontium- 90 content near $50 \%$ and be usable for direct conversion power production. Lower specific heat from strontium (e.g., less than $\sim 40 \%$ strontium- 90 ) could find applications as heat sources for a variety of applications, including downhole heaters for oil recovery, heating water lines, nil lines, and sewage lines in cold regions, heating sewage to increase digestion rates, and heating petroleum tanks and collection systems to keep the oil pumpable. Ihese heaters could be supplied by the lower strontium-90 content material in existing inventories.

Efficient use of strontium-90-fueled power sources will require design and development of higher efficiency conversion at a cost competitive with more conventional sources. In addition, an extensive education program should be undertaken to acquaint the public with the safety and reliability of these systems.

\section{Irradiation Sources}

Other major applications and potential applications of nuclear byproducts include irradiation for sterilization, clinical treatment, disinfestation, and chemical synthesis. Although a variety of isotopes have been used for special applications, most large irradiation sources have used cobalt -60 . Cesium-137, a byproduct from the nuclear fuel cycle, has now becn shown to meet the require-

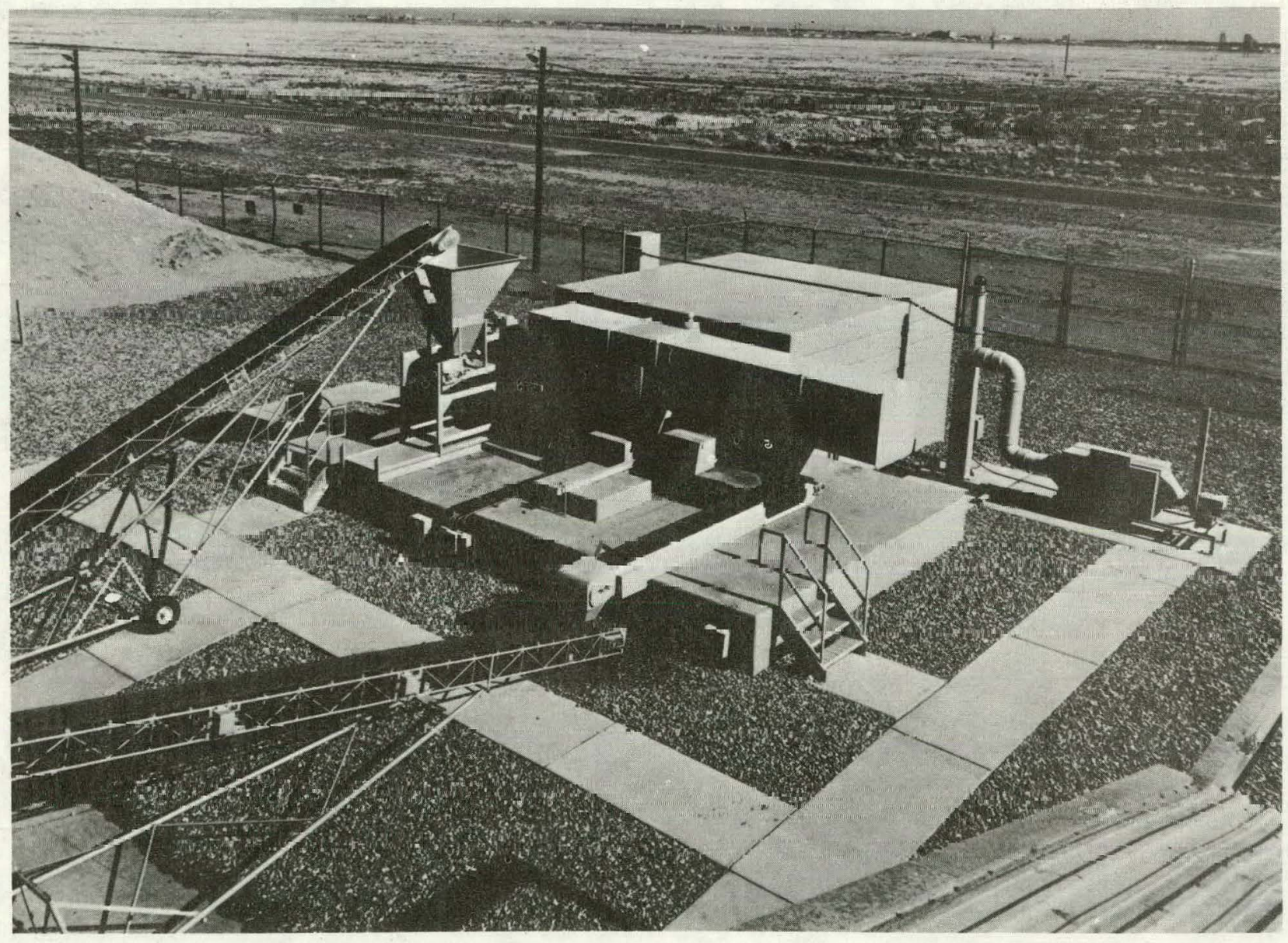

Cesium-137 Pilot-Plant Irradiator at Sandia National Laboratories 


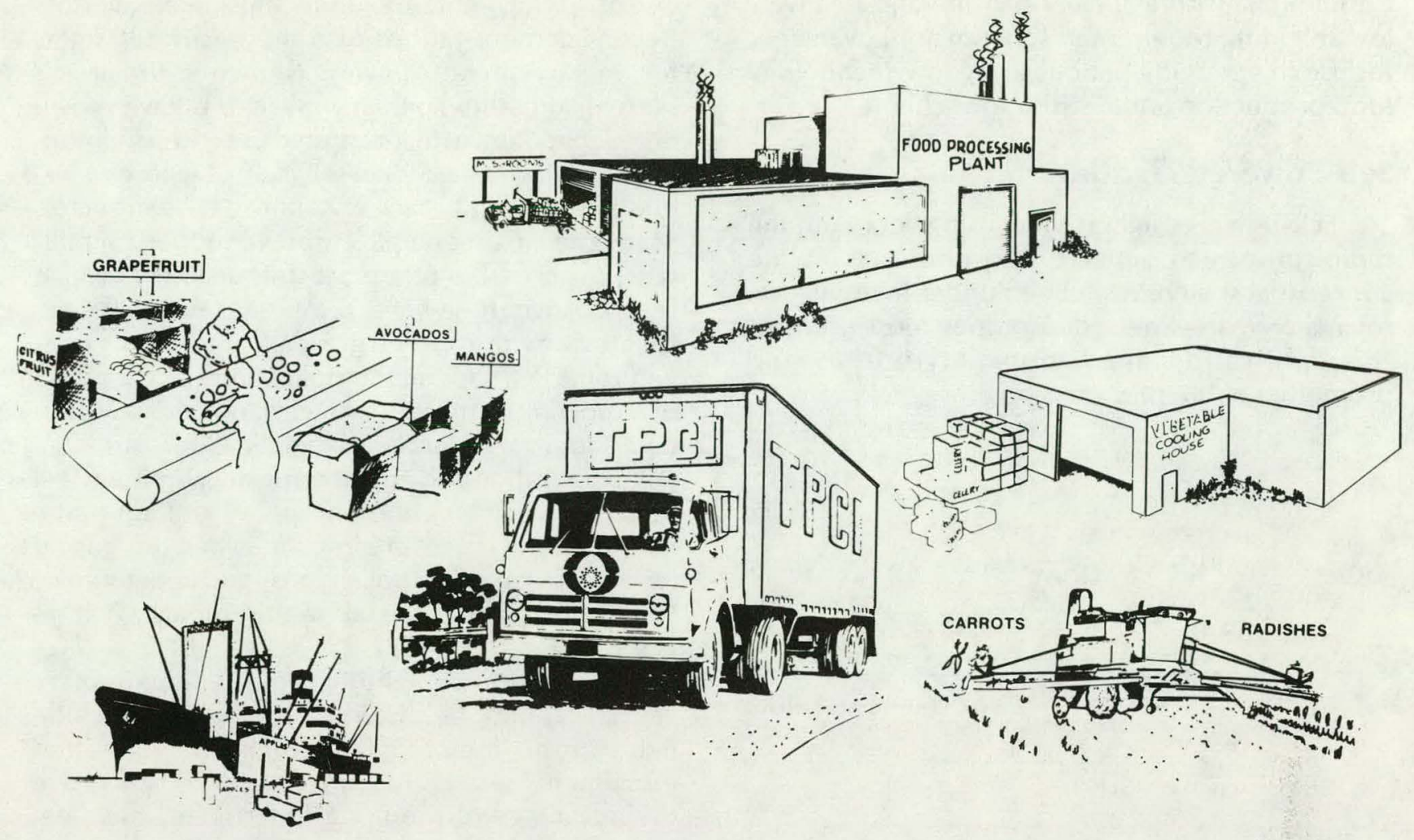

Transportable Cesium Irradiator

ments for many irradiation sources, and rapid progress has been made in identifying applications.

Demonstration of the irradiation of sewage sludge and to some extent citrus fruit has been accomplished in a 1-MCi (megacurie) cesium-137 irradiator at the Sandia National Laboratories. Results from the Sandia irradiation tests have led to the design of a municipal sewage sludge irradiator that eliminates bacterial, parasitic, fungal, and viral pathogens, rendering the sludge usable as a fertilizer or soil conditioner, or as a feed for livestock. Presently two cities, Albuquerque, New Mexico, and Idaho Falls, Idaho, are investigating the use of these technologies, and a demonstration plant at Albuquerque is expected to be under construction shortly.

Irradiation of food is rapidly becoming an acceptable technique for disinfestation and preservation. In fact, with the present concerns about the use of potential carcinogens for fumigation of food (e.g., ethylene dibromide), irradiation may become the preferred technique for many applications. Preliminary designs are complete and work is proceed- ing rapidly on cesium-137 irradiators for fruits, nuts, field crops, and pork. Researchers have shown that a dose of only $24 \mathrm{krad}$ of radiation will effectively disinfest grapefruit infested with Caribbean fruit fly larvae and 10 to $30 \mathrm{krad}$ disinfests pork of the parasitic nematode, trichinella spiralis.

It appears that irradiation may be useful for the treatment of many field crops and other foods. Adequate testing of the parameters can best be accomplished with a transportable cesium irradiator (TPCI), depicted here in the conceptual drawing. For fruits and field crops, the dose required and any secondary effects, such as changes in texture and taste, can be tested effectively only near the harvest site. A promising preliminary design enabling separate transport of the irradiation chamber and the cesium-137 source has been completed.

The use of food irradiation as a resource conservation measure is particularly applicable to the problem of world hunger. The U.S. Agency for International Development (AID), in conjunction with DOE and the World Health Organization, is investigating this technology to prevent food loss 
and improve its nutritive value, a measure that is potentially significant in developing countries. Cesium-137, with a 30 -year half-life and relatively low shielding requirements, has major advantages for use in emerging nations using low-technology food production and distribution schemes.

\section{Self-Powered Lighting}

Self-powered light sources using beta-emitting radioisotopes to activate phosphors (as in the conceptual sketch) have been under investigation for many years. The radioisotopes most used for this application are tritium, krypton-85 and promethium-147.

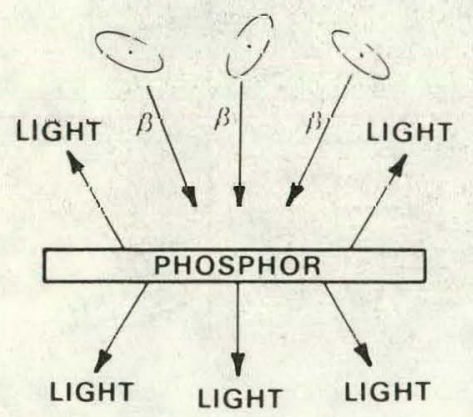

GAS - KRYPTON-85 OR TRITIUM

SOLID - PROMETHIUM

Technical Concept for Self-Powered Lighting
Television viewers remember pictures of the docking of the first spacecraft, using promethium147-powered lights to guide final maneuvering. Recent demonstrations of tritium-activated lights for military aircraft runways (shown in the artist's sketch) and other combat applications have shown excellent potential for expanded use. These demonstrations have also shown that self-powered radioluminescent lights can serve in the civilian sector. Many civilian uses parallel those identified for military purposes, but others are unique to the civilian sector. Since these lights require no external electrical power, they have a great advantage over conventional lights for many applications. The logistics of supplying batteries or electric power are eliminated for remote or tactical applications.

Application and engıneering development will focus on improving the phosphors and light pipe contigurations to get greater intensities, design and testing for specific applications, and meeting the institutional and societal requirements such as licensing.

In addition to lighting remote or temporary aircraft landing fields, other applications include lights for marine navigation, highways, signs, and instrument lighting. In general, tritium lights have the advantage of requiring little or no shielding, while the fission gas, krypton-85, has the advantage

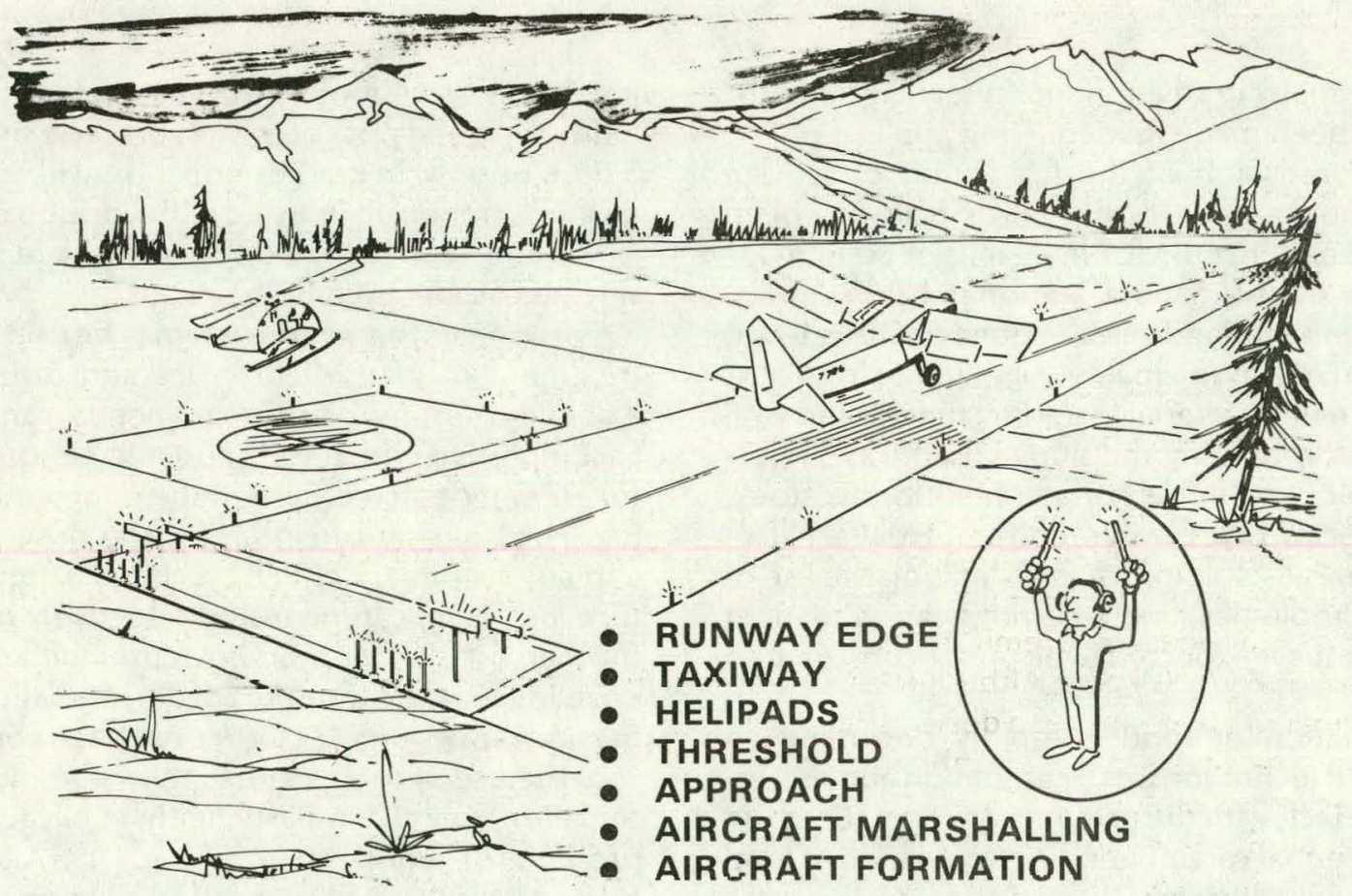

Remote Runway Lighting Using Self-Powered Radioluminescent Lights 


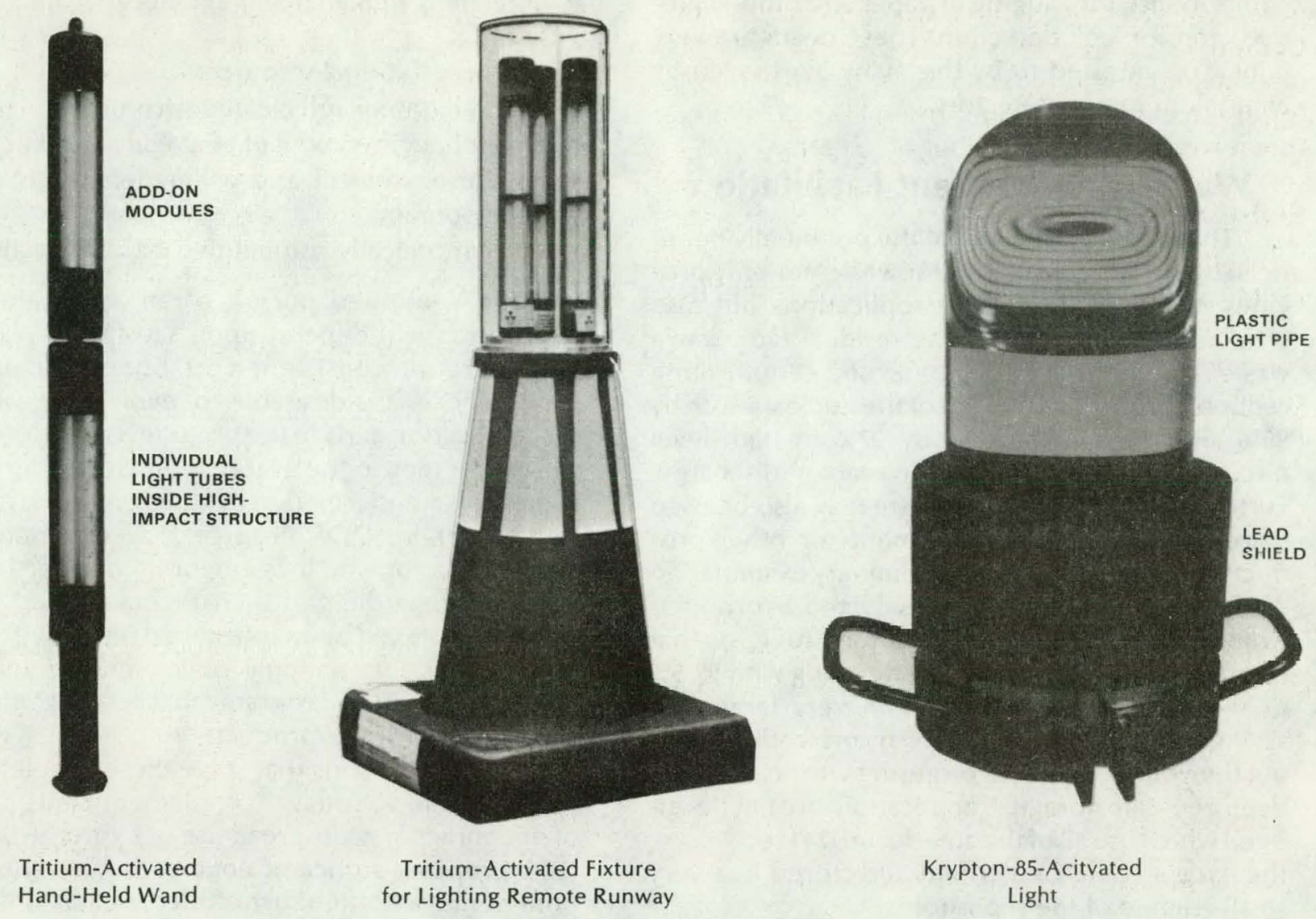

Three of Several Configurations of Self-Powered Lights Being Developed at Oak Ridge National Laboratory

of yielding more light for a given quantity of gas. Three configurations are depicted here. Specialized applications and the availability of the radioactive isotopes may be expected to dictate which isotope is used.

\section{Strategic Platinum Group Metals}

Spent nuclear fuels contain significant quantities of three of the platinum group metalsruthenium, rhodium, and palladium - plus a related element, technetium, which is nearly absent in nature. Fission-product technetium is essentially technetium-99, a weak beta emitter (0.29 MeV) with a half-life of $2 \times 10^{5}$ years. Although beneficial uses of technetium have not been demonstrated, its usefulness as a catalyst, a corrosion inhibitor, and as a coating to prevent biofouling is being considered.

Critical applications for the ruthenium, rhodium, and palladium are well established and, since the supply of these and other noble metals is almost entirely from foreign sources (the USSR and South Africa), they are considered strategic materials.
Thus there is considerable incentive to recover them from nuclear fuels. The technical feasibility of using fission-product noble metals extensively in industry depends upon resolution of three major problems: 1) They must be thoroughly decontaminated from all other radioactive materials in the waste stream. 2) They must be separated from one another in high purity to minimize contamination of the ruthenium and rhodium with the long-lived palladium-107 and the contamination of the palladium with the more damaging ruthenium-106 and rhodium-102m. 3) Applications selected must provide appropriate control of radioactivity or the radioisotopes must be removed by isotope separation techniques or normal decay.

\section{Other Applications}

Other applications have been considered for nuclear byproducts and some have been used for many years. Most notable among these applications are the use of americium-241 for oil-well logging and for smoke detection, and the use of krypton-85 for flaw detection in metals and electronics 
components, for gauging in paper and other materials, and for leak detection. These needs are very critical, as attested to by the many lives saved by americium smoke detectors.

\section{Waste Management Facilitation}

The recovery of many of the potentially beneficial byproducts from nuclear waste not only provides materials for critical applications but also simplifies the handling of the residual radioactive waste. The removal of strontium and cesium alone reduces the thermal burden of the nuclear waste by $95 \%$ and the gamma flux by $97 \%$ in high-level nuclear wastes 30 years after reactor discharge. Further partitioning of the waste may also be used to remove transuranium elements or other products for beneficial use. A preliminary examination of the impact of removal of selected byproducts from the nuclear wastes at Hanford suggests that removal of strontium and cesium along with $99.5 \%$ of the americium may result in very large cost savings (about 1 billion dollars) by markedly reducing the volume of waste requiring vitrification and deep geologic storage. If applications are not developed which use all of the americium-241 recovered, the excess could be vitrified and stored in a very small volume of the repository.

Similar schemes for reducing the volume of waste requiring vitrification and deep geologic storage will be examined, with the resultant cost savings, at the Savannah River Plant. This reduction will require removal of several transuranium elements because of significant differences in the reactor fuel and fuel processing schemes from those at Hanfurd.

\section{Byproducts Research, Development and Demonstration Plan}

To advance the technology for use of byproducts from nuclear fuels to the greatest extent practical, a plan has been developed to give guidance to the program and to potential investigators. There are an unlimited number of byproduct applications that could be investigated, but there are limited resources available. Therefore, the areas for major emphasis were selected on the basis of the following guiding principles:

- meet critical need for national defense

- provide potential benefit to nuclear waste management
- meet basic human needs and improve quality of life

- conserve national resources

- maintain safety and clean environment

- develop an inventory of strategic materials

- have user interest and willingness to share in development

- be economically competitive with alternatives.

The continued pursuit of an application of byproducts will depend upon satisfactory results from careful, consistent cost/benefit analyses. Furthermore, it is desirable to involve the user of the application early in the program and to transfer the technology to the user or ultimate producer as soon as a potential market has been demonstrated, thus conserving DOE resources. Past commercialization of, or private investment in, nuclear-based ventures, regardless of their technical merit, has been discouraged by unanticipated restrictive regulation, a variable national policy and fluctuating public acceptance. Programs that foster commercial utilization of byproducts from nuclear waste must include actions that solve these problems as well as technical issues. In implementing its policy of encouraging widespread use of byproducts, the DOE proposes sufficient engineering demonstrations of first-of-a-kind byproduct applications that technical operability, safety, environmental and public acceptability, and cost-effectiveness are established for each generic application. Such rapid and effective technology transfer will ensure the developmental maturity required to stabilize market conditions and attract private investment.

Consistent with this strategy, the DOE will emphasıze joint ventures with interested parties in other Federal agencies and in States, cities, and industry in which each partner has an economic stake and pays some portion of the cost. An example of this cooperative support is shown graphically for low-dose irradiation of foods. DOE participation will normally be limited to one engineering demonstration of a specific type of new technology or a specific new application of technology. In some instances second or third demonstrations may be necessary to accomplish the objectives cited above, in which case DOE involvement would be minimized and focused primarily on conceptual design, health, safety and environmental control. In all cases, the supply of byproduct sources would involve DOE and its contractors. The DOE's commitment to the operation of an engineering prototype will be defined in the initiating agreements 


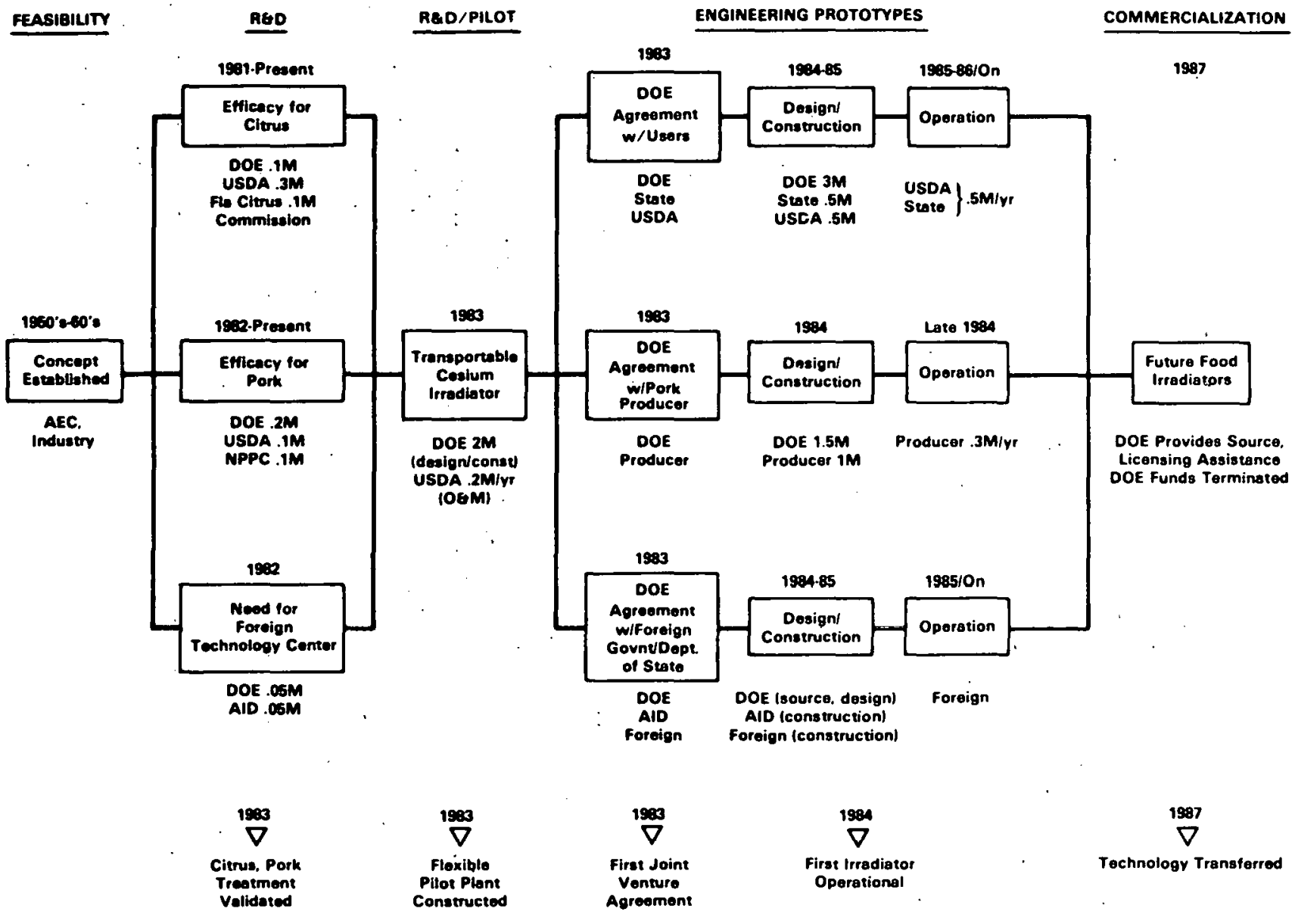

Cooperative Support of Low-Dose Cesium-137 Food Irradiation Program

and will be limited to four or five years, after which the facility and its operation will be the sole responsibility of the user agency. Emphasized will be technologies that appear ready for widespread use without future DOE funding. The DOE will continue to seek opportunities for byproduct utilization that require minimal or no incremental funding.

The cost of the byproducts will be based on the actual cost of recovery, purification, and encapsulation, with due consideration for savings in the management of the nuclear waste. This plan will necessarily include a continued search for new applications for the wide variety of byproducts available, along with an examination of methods for recovery.

\section{RD\&D Areas}

After due consideration of the principles described, the following six areas have been selected for the initial thrust of the byproducts program:
1) heat and power sources, 2) food and sludge irradiators, 3) self-powered lighting, 4) strategic noble metal recovery, 5) inert-gas applications, and 6) supporting studies. A summary description of the plan in each of these areas is given, followed by a list of the objectives and dates and a table showing the projected funding requirements for this program.

\section{Heat and Power Sources}

Although radioisotope-fueled electric power sources have been used for several years, there is now a potential for a very large expansion of their use for specialized military applications and commercial uses. This increased use places new emphasis on development and demonstration of higher efficiency devices, on recovery and encapsulation of the isotopes, and on safety and control. Therefore a major effort will be undertaken to develop both the applications and the supply of the iso- 
topes, principally strontium-90, to meet these important national needs. The initial effort will involve coordination with the Department of Defense (DOD) to identify, define, and prioritize the potential application, followed by design and demonstration of RTGs and advanced highefficiency converters specific to these applications. It will be the goal of this program to design and construct devices yielding at least $8 \%$ conversion efficiency RTGs and $25-40 \%$ efficient thermal mechanical converters which require little or no maintenance and no refueling or monitoring for periods of 10 to 15 years. At the same time, the supply of the byproduct fuel (e.g., strontium-90, plutonium-238, and krypton-85) will be further developed and refined. Facilities will be constructed or renovated as required and capsules designed and fabricated to ensure efficiency and safety of operation. The ultimate goal will be to have demonstrated power sources that meet specialized needs and to ensure the supply of sufficient fuel to meet the demand.

\section{Irradiator Demonstration}

Cesium-137 irradiator concepts have been developed and tested using the Sandia Irradiator. This facility will continue to operate to examine the irradiation parameters for a wide variety of applications. The major thrust of future work will be to design, construct, and undertake joint ventures for demonstration plants for sewage sludge irradiation, fruit irradiation, and pork irradiation, and to build and test a general-purpose transportable irradiator for field crops.

The initial demonstration of a specific technology (e.g., sewage sludge irradiation) may involve major input from DOE and its contractors to facilitate industrial and public acceptance of the process. In some instances, second or third demonstrations may be necessary, in which case DOE involvement would be minimized and focus primarily on health, safety, and environmental control. In all cases, the supply of the irradiation source would involve DOE and its contractors, as would ultimate disposal of the source at the end of its useful life.

Congress has appropriated funds for first-of-akind demonstrations of cesium-137 irradiators in an effort to encourage their earlier and more widespread use by removing institutional, regulatory, and any remaining technical uncertainties. Three full-size municipal sludge irradiator demonstra- tions could achieve the byproducts technology transfer strategy provided that the sites are suitably chosen with varying but representative sewage treatment processes. The cesium-137 is available at no incremental cost as a byproduct of DOE Defense Waste processing.

The technology transfer strategy for cesium food disinfestation recognizes the uniquely different aspects of Florida citrus fruit handling, packaging, and shipping techniques versus the techniques used for California fruits and vegetables. A full-size irradiator is proposed for each state. A stationary unit is proposed for Florida with its centralized logistical approach while a portable unit is being considered for California due to the dispersed and independent nature of its fruit and vegetable industry. The adaptation of the portable fruit irradiator to pork irradiation should be adequate to minimize the tront-end risk and to encourage investment by the private sector.

The ultimate goal is to complete demunsidtions and transfer the technology for safe, environmentally acceptable, and economically attractlve cesium-137 irradiators to the privatc scctor. Cooperative funding will be sought from other government agencies and potential users.

\section{Self-Powered Light Development}

Interest in low-level lighting using both krypton and tritium has increased rapidly in the past 2 or 3 years. The current and ongoing program has in some instances reached the hardware development and demonstration stage. Military airfield lighting for runway distance markers and for taxiway marking is into long-term testing programs. Bare-base (unimproved) runway edge and threshold lighting for rapid deployment forces is in the demonstration stage, and instrument lighting that is compatible with night vision equipment is in the early R\&D stages. Special underwater marking lights for use by special forces and civilian law enforcement applications are under review or in actual R\&D phases. The work to date has been jointly funded by DOD and DOE, with the DODfunded effort directed to specific requirements and DOE funding supporting major R\&D efforts.

Continued development of these techniques will require research on phosphors, examination of methods for improved-efficiency light production, and shielding for krypton-85 sources. In addition, new applications using infrared and underwater lights will require further development. Field 
testing will necessarily continue, and transfer of the technology to commercial fabricators will be the ultimate objective of the DOE-sponsored effort.

\section{Strategic Platinum Group Metal Recovery and Applications}

The strategic value of platinum group metals provides considerable incentive to continue development of methods for recovery and use of these materials from the nuclear fuel cycle. Work has recently been initiated to develop economical methods of recovery and purification compatible with current waste treatment practices. This work will continue with laboratory and pilot-scale testing of these techniques with both simulated and actual nuclear fuel products.

Studies have been conducted to develop a technique for recovering platinum group metals at Hanford during vitrification. Because of changes in the waste processing scheme, it will be necessary to reevaluate methods for removing platinum group metals earlier in the waste-handling process, and this evaluation is currently under way. Recovery of mercury, added as an aid to dissolution of the fuel cladding, is required prior to vitrification at SRP. Previous studies have shown that removal of palladium and rhodium with the mercury may be possible. Evaluation of this process is also under way.

Concurrently with this work, efforts will be undertaken to determine the health effects of using byproduct noble metals in selected applications and to evaluate isotope enrichment techniques for removing radioactivity to render the product suitable for uncontrolled application.

The strategy to be employed for recovery of strategic platinum group metals recognizes that rhodium, ruthenium and palladium byproducts from SRP and Hanford can be stored separately as part of the strategic reserve and recovered when it becomes cost-effective. Industry is developing technology that can be used for this purpose and will be willing to purify this material at its own risk if insurance can be given against future Federal regulatory or policy change. For example, LWR waste reprocessing will be necessary to supply sufficient material for private capital cost to be recovered.

\section{Inert -Gas Applications}

Krypton-85 is currently used in many critical applications, including nondestructive examination of metallic components and semiconductors, gauging of thin components in industry, leak- testing, and self-powered lights. In recent years the demand for this major nuclear byproduct has exceeded the recovery capacity. The continued development of applications for krypton-85 will be enhanced by development of an adequate supply.

Several potential applications for krypton-85 appear to have substantial promise. This would be particularly true if isotope enrichment were to develop into an economical source of enriched krypton-85. Techniques have recently been developed to implant krypton in metal matrices with a krypton content exceeding 10 atom \%. Thus, heat sources approaching $1 \mathrm{watt} / \mathrm{cm}^{3}$ are possible. Such heat sources appear to have potential for isotopicpowered batteries. The krypton-85 sources appear to have a safety advantage because the radioisotope is an inert gas immobilized in a metal matrix.

Work will be conducted to examine the potential for enriching krypton-85 and developing power sources as well as to continue the search for other possible uses. Simultaneously with the supply of krypton, large volumes of xenon will be recovered. The radioisotopes of xenon have short half-lives, and thus any radioactivity associated with the xenon fraction will be due to krypton- 85 and other impurities. The program will examine techniques for purification and application of the xenon product.

A major enhancement of the xenon supply would probably open the door to many applications of this valuable inert gas. Xenon has been suggested and successfully tested as an effective anesthetic and also has major advantages for use in vacuum tubes and light bulbs. Large-scale applications may develop in the chemical industry by virtue of xenon's ability to form certain highly reactive chemical compounds.

\section{Supporting Studies}

Although the major accomplishments are reflected in the specific areas listed above, the continued development of nuclear byproducts will depend on continuing supporting work. This work includes examination of the impact of byproduct recovery on waste management, the development of capsules and examination techniques to ensure the integrity of isotope-fueled sources and other materials, examination of the economics of isotope enrichment and development of techniques for enrichment as required, study of the cost-benefit of recycle of contaminated materials, and continuing development of new applications for nuclear 


\section{Milestone Schedule}

Heat and Power Sources

DOE/DOD Task Force Report

Higher Power Demonstration Unit

Improved Product Prototype Unit

Strontium-90 from Future PUREX

High-Efficiency Conversion Demo

Supply Power Sources for $C^{3}$ I

Supply Isotope Power Sources for Air Surveillance

\section{Cesium Irradiators}

First Sludgo Irradiator Joint Venture

Agiieement (DOE/Albuquerquc)

Albuquerque Irradiator Operational

Second Sludge Irradiator Joint Venture

Agreement

Second Irradiator Óperational

Third Sludge Irradiator Joint Venture

Agreement

Third Irradiator Operational

Foreign Sludge Irradiator Operational

Sludge Irradiation Technology Transferred

Transportable Cesium Irradiator

Pilot/Demo Plant

Fruit, Nut and Field Crop Irradiator Venture Agreement

Fruit, Nut and Field Crop Irradiator Operational

Pork Irradiator Joint Venture Agreement

Pork Irradiator Operational

Food Irradiation Technology Transferred

DOD/AID Agreement-Foreign Food Irradiator

\section{Self-Powered Lights}

Initial Demo of Tritium and Krypton-85 Lights

Complete Development and Testing for Military Use

Complete Optimization of Phosphor

Complete Technology T̄ransfer and Initiate

Commercial Manufacture

Joint Venture Agreement (State of Alaska/DOE)

Feasibility Study for Civilian Applications in Arctic (Joint Project DOE/State of Alaska)

Civilian Demonstration - Remote Arctic Runways (DOE/State of Alaska)

Complete Testing of Enhanced IR Lights

Complete Testing of Advanced Shielding/Optics

for Krypton-85 Lights

Complete R\&D for High-Efficiency Light Production

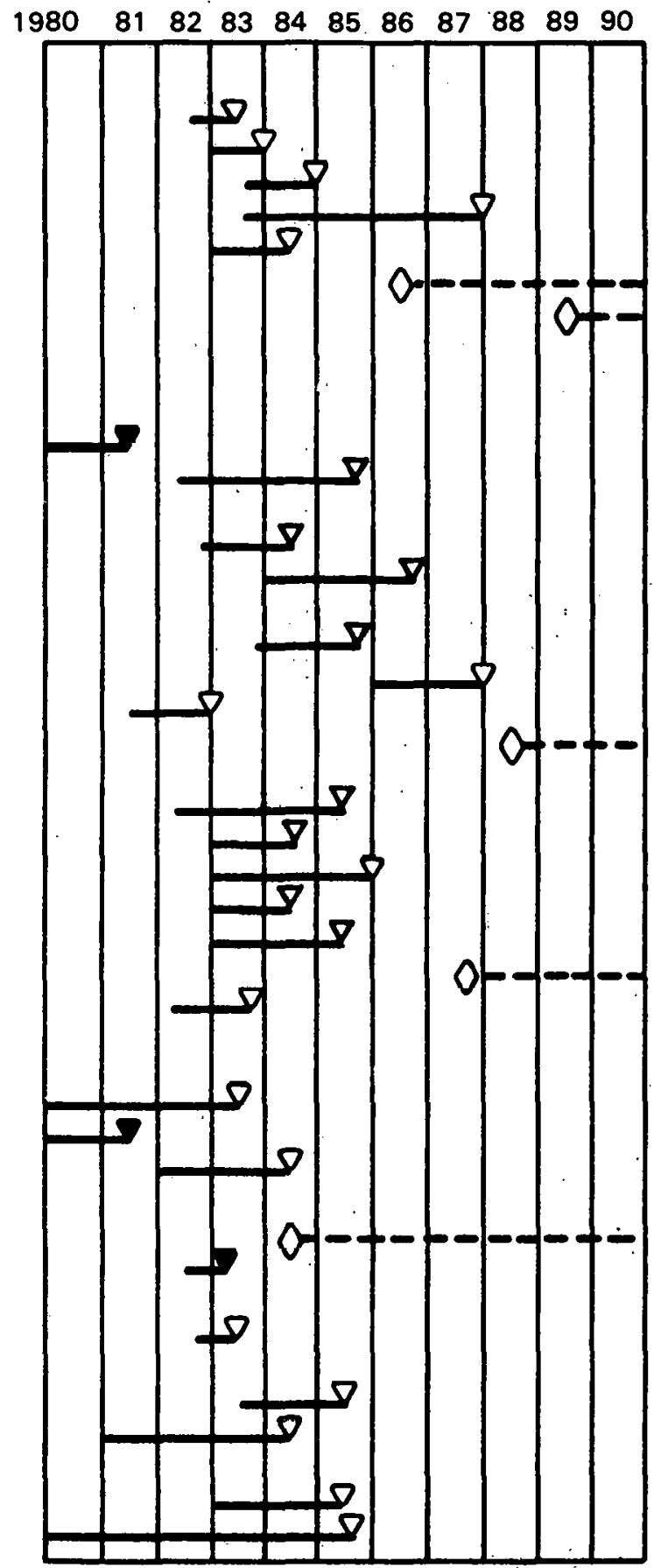




\section{Milestone Schedule}

Strategic Platinum Group Metals

Demonstrate Feasibility of Lead Extraction. Pilot Demonstration of Lead Extraction Determine Chemistry of Pt-group Metals in PUREX Preliminary Evaluation of Alternative Processeș and Select Reference :

Determine Occupational and Population Exposure . from Use of Fission-Product Pt-group Metals Examine Isotope Separation Alternatives Demonstrate' $\mathrm{Hg}$ Extraction of Pt-group Metals Extract Pt-group Metals from Hanford Waste Technology Transfer of Applications

\section{Inert-Gas Applications}

Applications Assessment :

Recommend Recovery. Techniques

\section{Supporting Activities "}

Analyze Impact on Waste Management Determine Feasibility of Advanced NDE for Byproduct Capsules

Complete Testing of NDE Monitoring Station Complete Validation Assessments of Isotope Enrichment of Strontium-90, Krypton-85, Pt-group Metals

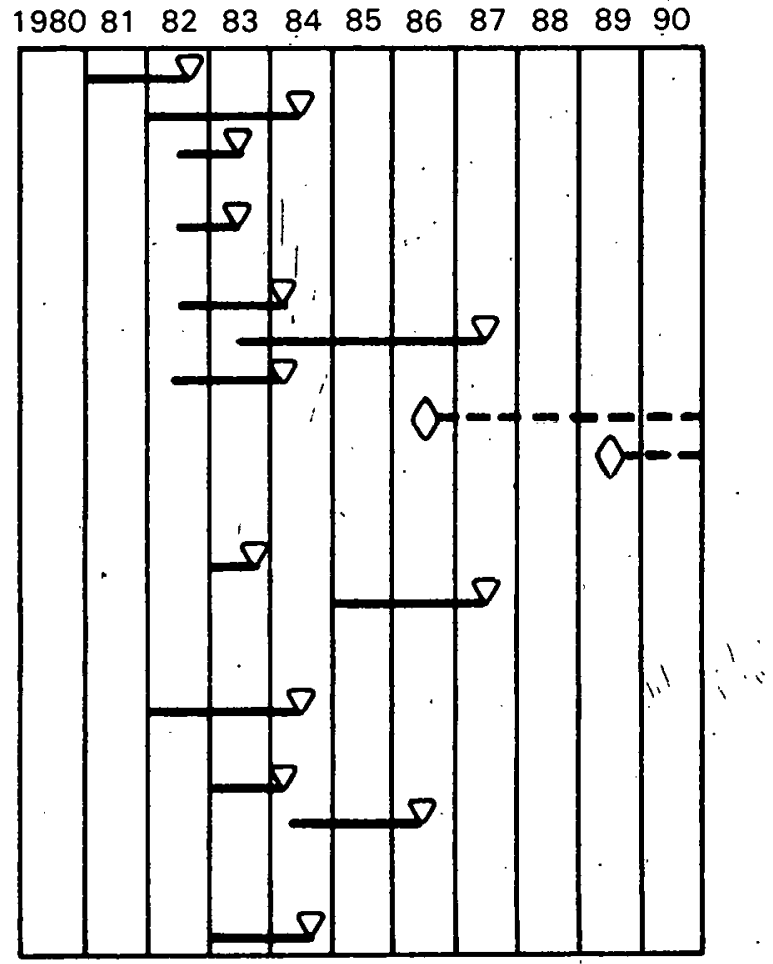
$\nabla$ Major Milestone
- Milestone Completed
. Transfer of Technology 
byproducts. The work included in this task will vary, depending upon the needs, but will be critical to the program's success.

\section{Milestone Schedule}

The chart shows the major milestones in supply and use of nuclear byproducts since 1980 and those projected through 1990. In addition to the major RD\&D milestones, we have included milestones for joint venture agreements and for technology transfer to the ultimate user of the byproducts.

\section{Projected Program Costs}

To realize the potential for beneficial application of nuclear byproducts; a substantial commitment of funds will be required of DOE, other government agencies, and potervial users and producers.

It is antiripated that DOE will lead in developing applications and constructing demonstration projects as well as in continuing the supply of byproducts. The early transfer of technology to the ultimate user or supplier is the goal of this program. A successful effort in ultimate application will not only require substantial funding through the byproducts program but a realization of the potential benefits in the management of nuclear waste.

The annual operating cost of the program ranges from 15 to 25 million dollars, including costsharing by industry and other agencies.

A substantial commitment will be required for construction in the various projects described earlier. A reasonable estimate of the costs of these projects is given only for those in which preconceptual cost estimates have been completed. For the other projects, cost estimates will be determined during the preconceptual design stages of the program.

The estimated annual capital cost for DOE ranges from 6 to 10 million dollars to support DOE's share of the joint venture line item projects.

The following is the projected budget requirement in RD\&D operating and equipment funds required for the byproducts program through 1985 and a listing of construction projects through 1987.

Total

Estimated

Cost, \$M

1. Transportable Cesium-1.37 Irradiation Demonstration

2. Albuquerque Sewage Sludge Irradiation Demonstration

3. Pork Irradiation Demonstration Plant

4. Fruit, Nut and Field Crop Irradiator Demonstration

5. Strontium-90 Recovery and Encapsulation Facility

6. Second Sewage Irradiator
1985

3.5

1985

2.5

1985

4.0

1985

3.0

1986

Not Determined

Costs, $\$$ in Millions

\begin{tabular}{|c|c|c|c|c|c|c|}
\hline \multirow[b]{2}{*}{ Tasks } & \multicolumn{2}{|c|}{ FY-1983 } & \multicolumn{2}{|c|}{ FY-1984 } & \multicolumn{2}{|c|}{ FY-1985 } \\
\hline & Operating & Capital & Operating & Capital & Operating & Capital \\
\hline Heat and power sources & 1.0 & - & 2.8 & - & 7.0 & - \\
\hline Irradiators & 3.0 & 5.0 & 5.0 & 5.0 & 3.0 & - \\
\hline Self powered lights & 0.75 & - & 0.75 & - & 0.9 & - \\
\hline $\begin{array}{l}\text { Strategic platinum-group } \\
\text { metal recovery and } \\
\text { applications }\end{array}$ & 0.4 & - & 1.0 & - & 1.0 & - \\
\hline Inert-Gas applications & 0.1 & - & 0.2 & - & 0.2 & - \\
\hline Supporting studies & 0.25 & - & 0.25 & - & 0.5 & - \\
\hline Capital Equipment & - & 1.0 & - & 0.6 & - & 0.5 \\
\hline Totals & 5.5 & 6.0 & 10.0 & 5.6 & 12.6 & 0.5 \\
\hline
\end{tabular}




\section{Concluding Statement}

Nuclear byproducts are a major national resource that has yet to be incorporated into the economy. The current Defense Byproducts Program is designed to match specific military and commercial needs with the availability of valuable products which are currently treated as waste at considerable expense in waste management costs. This program plan focuses on a few specific areas with the greatest potential for near-term development and application. It also recognizes the need for a continuing effort to develop new applications for byproducts and to continue to assess the impacts on waste management.

The entire program has been, and will continue to be, structured so as to ensure the safety of the public and maintain the purity of the environment. Social and institutional concerns have been recognized and will be handled appropriately. A significant effort will be undertaken to inform the public of the benefits of byproduct use and of the care being taken to ensure safe, efficient operation.

Additional funding sources will be sought from other government agencies and industrial users of the byproduct early in development of applications. Since many applications of byproducts are now identified and more will be developed as a result of this program, an attempt will be made to quantify, as far as possible, their selection on the basis of cost/benefit. A careful study of current and promising applications of byproducts, the availability of these materials from the defense and civilian fuel cycles, and the beneficial effect on waste management practices clearly dictates the need for a vigorous developmental effort to use these valuable materials in meeting critical national needs. 
UNITED STATES

DEPARTMENT OF ENERGY

WASHINGTON, D.C. 20585

OFFICIAL BUSINESS

PENALTY FOR PRIVATE USE, $\$ 300$
POSTAGE AND FEES PAID

U.S. DEPARTMENT OF ENERGY

DOE 350

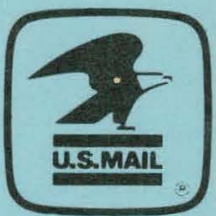

FIRST CLASS MAIL 